\title{
Energy intake, energy dispersion and body mass index interaction in adolescents
}

\author{
Saime Kucukkomurler ${ }^{1}$ \\ Omer Istik $^{2}$
}

\begin{abstract}
The aim of this study was to investigate dietary energy intake and energy dispersion among adolescents and to examine its relationship with Body Mass Index (BMI). Adolescents recalled food intake in the past 24 hours and energy intakes/expenditure were calculated. For the relation between BMI and energy intake percentage, ANOVA and Tukey post-hoc test were used. This research was performed in 2010 in Istanbul, Turkey. The study was carried out with 265 adolescents, 63.4\% girls, aged between 12-15. Girls and boys have BMI means of 18.19 \pm 2.69 and $20.42 \pm 4.85$ respectively. With respect to BMI, body fat percentage (BFP) was significantly different for both girls and boys $(\mathrm{p}<0.001)$. As BMI increased, so did BFP while body fluid rate (BFR) decreased. While the relation between daily total energy intake and BMI for boys was not statistically significant, it was significant for girls $(\mathrm{p}<0.01)$. The relation of energy percentage from fat and BMI for both boys and girls was significant (boys $\mathrm{p}>0.5$, girls $\mathrm{p}<0.01$ ). While the relation of energy rate from carbohydrates and BMI was not significant for girls, it was significant for boys $(p<0.001)$. In the current study, even though the total energy intake of adolescents was not above the requirements of their age group, the energy intake from fats was mostly higher than the rates recommended. A high percentage of energy intake from fats over a prolonged period may result in obesity.
\end{abstract}

Keywords: Adolescent; BMI; Energy Intake; Energy Dispersion.

\section{Introduction}

Adolescence is a period when physical growth rate is quite high. Biological, emotional, social, and cognitive changes directly affect nutritional habits depending on the level of physical growth. In order to meet the growing needs of children during the period of adolescence, it is necessary to adopt good nutrition habits. Such issues as obesity, hypertension, cholesterol, problematic eating habits, lack of physical activity among others come to the forefront of adolescent nutrition problems.

Studies conducted on the characteristics of diets when gaining weight predominantly cover the relation between total calorie intake and BMI in a general sense (Ebbeling, Pawlak and Ludwig, 2002; Atikessé, et al, 2010). The impact of the overall rates of total calories coming from proteins, carbohydrates and fats on BMI values have been investigated to a lesser extent (Zalilah, et al, 2006; Humenikova and Gates, 2007; Receveur, et al, 2008). An investigation into calorie distribution in one's diet will provide an evaluation for the direction of adolescents' food choices and their habits.

\footnotetext{
1 Assoc. Prof. Dr, Gazi University, Tourism Faculty, Gastronomy and Kitchen Arts. Turkey/Ankara saimek@gazi.edu.tr

2 M.Sc., Gazi University, Faculty of Vocational Education, Food and Nutrition Department. Turkey/Ankara stkomr@hotmail.com
} 
Determining the nutrition habits of adolescents is of significance when guiding them towards good nutrition, thus weight control can be achieved.

The purpose of the current study was to investigate the energy distribution of the food adolescents consume. It aims to investigate the total energy consumption of adolescents as well as the effect of the energy supplied through fats and carbohydrates on BMI. The investigation of energy distribution among adolescents is one of the most important factors showing the effect of food choice on BMI. The investigation into the source of energy supplied in comparison with BMI is one of the leading factors showing which direction food choices or habits adolescents are taking. In addition, current studies show that body fat rate percentage (BFP) has been used as an indicator of obesity (Kyle, et al, 2004). Therefore, this study deals with the relation of BMI and BFP/ body fluid rate (BFR) percentage. The data obtained could be beneficial for adolescents to attain true nutrition habits.

\section{Materials and methods}

\subsection{Study population}

Three hundred students between the ages of 12-15 volunteered for this study. Answers from 35 participants were deemed unreliable and thus were excluded and the total number of participants was 265 people. The demographic survey was administered in March 2010. The research was carried out at a state school attended by people living in a suburban region of Istanbul with a lower income and coming mostly from poor families. This school was chosen based on convenience as one of the researchers worked at this school. Because this research involves survey procedures, it was exempt from Institutional Review Board approval (Institutional review board approval code of federal regulations (45 CFR 46). 2013).

\subsection{Anthropometric measurements}

Body analysis was measured by the researchers using Tanita BC-420. Body analysis measurement entailed placing the scale on a flat surface next to the students with bare feet and light clothing. Using the height data, the BMI $\left(\mathrm{kg} / \mathrm{m}^{2}\right)$ values of the students were calculated with Tanita BC-420. Students' body weight, BFP and BFR were determined through Tanita BC-420. The bioelectrical impedance analysis (BIA) method is a more affordable but less accurate way to estimate BFP (Kyle, et al, 2004; Gallagher, et al, 2000; Gibson, 2005).

\subsection{Calculating energy intake and consumption}

Using "Computer Assisted Nutrition Program, Nutrition Information System Anthropometry; Energy Level" developed for Turkey, nutrition consumed in a day was recorded by participants recalling the last 24 hours and energy intake was calculated based on these recordings Estimated energy consumptions were calculated from physical activities reported by participants. Durations of activities, such as sleeping, sitting, walking, and running were reported by the participants. Following this, researchers calculated the estimated energy consumption using these values with the help of 'BeBis' computer program (Bebis (Nutrition information system), 2004).

After determining the food adolescents consumed and their amounts (g), using the BeBis program developed for Turkey, the daily energy intake levels were compared with the daily energy intake levels recommended for Turkey adapted from Recommended Dietary Allowance/Recommended Daily intake (RDA: The recommended daily amount of food consumption by FDA) data taking the age and gender criteria into consideration for the Nutrition Guide Recommended for Turkey (NGPT, 2004).

Daily total energy intake of the adolescents, and the percentage distribution coming from proteins fats and carbohydrates were evaluated using the nutrition guide developed for Turkey. The 
Kucukkomurler S., \& Istik O. (2016). Energy intake, energy dispersion and body mass index interaction in adolescents. Journal of Human Sciences, 13(2), 2793-2803. doi:10.14687/jhs.v13i2.3849

energy intake distribution recommended for Turkey is as follows: $10-15 \%$ coming from proteins, $55-60 \%$ coming from carbohydrates and $25-30 \%$ coming from fats (NGPT, 2004).

\subsection{Classification of BMI, BFR, BFP}

For the analysis of data, the percentile standards of WHO (2007) were used in determining BMI, calculated based on age and gender. For this data, $<15$ was taken as underweight (UW), 15-85 was taken as normal weight (NW) and $\geq 85$ was taken as over weight (OW) (Wang and Wang, 2002). No obese adolescents partook in this research. Since the development of boys and girls are different during the period of adolescence, BMI values in terms of age and gender were investigated in detail. For BFR, $<55 \%$ was taken as low, $55-70 \%$ was taken as normal and $>70 \%$ was taken as high. For BFP, $<17 \%$ was taken as low, $17-25 \%$ was taken as normal and $>25 \%$ was taken as high (Kyle, et al, 2004; Gibson, 2005).

\subsection{Statistical analyses}

All statistical analyses were performed using SPSS v.16.0 (SPSS Inc. Chicago. IL). Descriptive statistics, including the means and frequency percentages, were used to summarise the data. For the analysis of the relation between BMI and energy intake percentage, ANOVA was used and Tukey post-hoc test was used to determine which group(s) differed from each other.

\section{Results}

\subsection{Distribution of adolescents with respect to age, gender and BMI}

In the current study, 256 adolescent students between the ages of 12-15 attending a state primary school in the district of Esenler, Istanbul participated. $63.4 \%$ of them were girls, $46.0 \%$ were age 14.Mean age was $13.60 \pm 0.77$ for boys and $13.46 \pm 0.83$ for girls. BMI distributions of the adolescents with respect to age and gender are given in Table 1. For the BMI values, $45.4 \%$ of the boys were NW, while $60.1 \%$ of the girls were NW.

The rate of UW 13 year-old students was slightly higher compared to 12 year-olds: $33.3 \%$ and $43.2 \%$. The rate of OW 12 year-old students was the same as those who were UW.BMI means varied between $18.19 \pm 2.69$ and $20.42 \pm 4.85$. No statistically significant differences were found between the BMI values of boy and girl adolescents. The rate of UW 14 and 15 year-old boy students was lower than those of 12 year-olds.

\subsection{The factors affecting energy use of adolescents with respect to BMI}

The arithmetic means of energy intake, energy distributions with respect to BMI values and gender, standard deviations, ANOVA results, and the results of the Tukey post-hoc test are given In Table 2.

\subsection{BFR and BFP, according to the BMI}

BFR of boys was normal for all BMI groups. For girls, BFR was under normal values for OW students (49.34 \pm 4.17$)$. BFP was much lower for NW than for UW boys (6.64 \pm 2.45$)$. BFP was higher than normal for OW girls (32.60土5.67). With respect to BMI, the difference for BFP was statistically significant for both girls and boys $(\mathrm{p}=0.000)$. As BMI increased, BFP rate increased and BFR rate decreased. 
Kucukkomurler S., \& Istik O. (2016). Energy intake, energy dispersion and body mass index interaction in adolescents. Journal of Human Sciences, 13(2), 2793-2803. doi:10.14687/jhs.v13i2.3849

Table 1. Distribution of Adolescents with Respect to Age, Gender and BMI ( $n=265)$

\begin{tabular}{|c|c|c|c|c|c|c|c|c|}
\hline \multirow{2}{*}{\multicolumn{2}{|c|}{ BMI (Percentile) }} & \multicolumn{2}{|c|}{ UW } & \multicolumn{2}{|c|}{ NW } & \multicolumn{2}{|c|}{ OW } & \multirow{2}{*}{$\begin{array}{c}\text { BMI } \\
\bar{X} \text { S }\end{array}$} \\
\hline & & \multicolumn{2}{|c|}{$<5$ th } & \multicolumn{2}{|c|}{$\leq 5$ th $-<85$ th } & \multicolumn{2}{|c|}{$\geq 85$ th $-<95$ th } & \\
\hline Age & Gender & $\mathrm{n}$ & $\%$ & $\mathbf{n}$ & $\%$ & $\mathbf{n}$ & $\%$ & \\
\hline \multirow{2}{*}{12} & $\begin{array}{l}\text { Boy } \\
(n: 6)\end{array}$ & 2 & 33.3 & 2 & 33.3 & 2 & 33.3 & $18.51 \pm 4.53$ \\
\hline & $\begin{array}{c}\text { Girl } \\
(\mathrm{n}: 25)\end{array}$ & 4 & 16.0 & 18 & 72.0 & 3 & 12.0 & $18.19 \pm 2.69$ \\
\hline \multirow{2}{*}{13} & $\begin{array}{c}\text { Boy } \\
(\mathrm{n}: 37)\end{array}$ & 16 & 43.2 & 13 & 35.2 & 8 & 21.6 & $18.44 \pm 3.47$ \\
\hline & $\begin{array}{c}\text { Girl } \\
(\mathrm{n}: 52)\end{array}$ & 18 & 34.6 & 27 & 51.9 & 7 & 13.5 & $18.95 \pm 3.55$ \\
\hline \multirow{2}{*}{14} & $\begin{array}{c}\text { Boy } \\
(\mathrm{n}: 43)\end{array}$ & 9 & 20.9 & 22 & 51.2 & 12 & 27.9 & $19.87 \pm 3.27$ \\
\hline & $\begin{array}{c}\text { Girl } \\
(\mathrm{n}: 79)\end{array}$ & 16 & 20.3 & 49 & 62.0 & 14 & 17.7 & $20.14 \pm 3.29$ \\
\hline \multirow{2}{*}{15} & $\begin{array}{c}\text { Boy } \\
(\mathrm{n}: 11)\end{array}$ & 3 & 27.3 & 6 & 54.5 & 2 & 18.2 & $19.53 \pm 2.94$ \\
\hline & $\begin{array}{c}\text { Girl } \\
(\mathrm{n}: 12)\end{array}$ & 3 & 25.0 & 7 & 58.3 & 2 & 16.7 & $20.42 \pm 4.85$ \\
\hline
\end{tabular}

(Underweight: UW, Normal weight: NW, Overweight: OW)

\subsection{According to BMI or total energy expenditure}

Daily total energy intake for the adolescents was higher for boys compared to girls. No interaction was found for boys between BMI values and calorie consumptions $(\mathrm{p}=0.627)$. For girls, as BMI value increased, daily energy spending decreased. While the relation between daily energy intake of boys and BMI was not statistically significant ( $(\mathrm{P}>0.05)$, a significant relation was found between total energy intake and BMI for girls $(p=0.019)$, however, the interaction was not in the expected direction.

\subsection{Energy from protein, according to BMI}

The mean energy coming from protein was normal in all groups for boys. For girls, the percentage of energy coming from protein decreased for UW and OW students $(11.43 \pm 2.06$, 12.44 \pm 3.68 ). While there was no statistically significant difference between BMI groups for boys with respect to the percentage of energy coming from protein, this difference was significant for girls $(\mathrm{p}=0.019)$. 
Kucukkomurler S., \& Istik O. (2016). Energy intake, energy dispersion and body mass index interaction in adolescents. Journal of Human Sciences, 13(2), 2793-2803. doi:10.14687/jhs.v13i2.3849

Table 2. The Factors Affecting Energy Use of Adolescents with Respect to BMI ( $n=265)$.

\begin{tabular}{|c|c|c|c|c|c|c|c|}
\hline \multirow{2}{*}{$\begin{array}{l}\text { Variables } \\
\text { (Normal } \\
\text { Values) }\end{array}$} & \multirow[b]{2}{*}{$\sum_{m}^{B}$} & \multicolumn{2}{|c|}{$\overline{\mathrm{x}} \pm \mathrm{S}$} & \multicolumn{4}{|c|}{ Significance between The Groups } \\
\hline & & Boy(n:97) & Girl(n:148) & Boy & Girl & Boy & Girl \\
\hline \multirow{3}{*}{$\begin{array}{l}\text { BFR } \\
55-70 \%\end{array}$} & 1 & $68.34 \pm 1.80$ & $63.85 \pm 3.12$ & \multirow{3}{*}{$0.000^{* * *}$} & \multirow{3}{*}{$0.000 * * *$} & \multirow{3}{*}{$\begin{array}{l}1-2 \\
3-1 \\
2-3\end{array}$} & \multirow{3}{*}{$\begin{array}{l}1-2 \\
3-1 \\
2-3\end{array}$} \\
\hline & 2 & $64.25 \pm 3.01$ & $57.27 \pm 3.11$ & & & & \\
\hline & 3 & $55.83 \pm 8.06$ & $49.34 \pm 4.17$ & & & & \\
\hline \multirow{3}{*}{$\begin{array}{l}\text { BFP } \\
17-25 \%\end{array}$} & 1 & $6.64 \pm 2.45$ & $12.77 \pm 4.27$ & \multirow{3}{*}{$0.000^{* * *}$} & \multirow{3}{*}{$0.000^{* * *}$} & $1-2$ & $1-2$ \\
\hline & 2 & $12.21 \pm 4.13$ & $21.77 \pm 4.26$ & & & $3-1$ & $3-1$ \\
\hline & 3 & $21.77 \pm 4.96$ & $32.60 \pm 5.67$ & & & $2-3$ & $2-3$ \\
\hline \multirow{3}{*}{$\begin{array}{l}\text { Energy } \\
\text { intake } \\
\text { (cal/d) }\end{array}$} & 1 & $2663.37 \pm 618.77$ & $2525.02 \pm 465.44$ & \multirow{3}{*}{0.627} & \multirow{3}{*}{$0.019 *$} & \multirow{3}{*}{-} & \multirow{3}{*}{$1-2$} \\
\hline & 2 & $2562.64 \pm 590.62$ & $2253.55 \pm 533.95$ & & & & \\
\hline & 3 & $2681.76 \pm 380.92$ & $2232.44 \pm 742.94$ & & & & \\
\hline \multirow{3}{*}{$\begin{array}{l}\text { Protein } \\
10-15 \%\end{array}$} & 1 & $13.83 \pm 2.52$ & $11.43 \pm 2.06$ & \multirow{3}{*}{0.159} & \multirow{3}{*}{$0.002^{* *}$} & \multirow{3}{*}{-} & \multirow{3}{*}{$1-2$} \\
\hline & 2 & $12.80 \pm 2.98$ & $13.06 \pm 2.37$ & & & & \\
\hline & 3 & $14.16 \pm 3.56$ & $12.44 \pm 3.68$ & & & & \\
\hline \multirow{3}{*}{$\begin{array}{l}\text { Fat } \\
25-30 \%\end{array}$} & 1 & $35.00 \pm 7.12$ & $38.65 \pm 7.27$ & \multirow{3}{*}{$0.011^{*}$} & \multirow{3}{*}{$0.009 * *$} & \multirow{3}{*}{$\begin{array}{l}1-3 \\
2-3\end{array}$} & \multirow{3}{*}{$1-2$} \\
\hline & 2 & $34.19 \pm 8.15$ & $34.73 \pm 6.46$ & & & & \\
\hline & 3 & $40.20 \pm 8.83$ & $36.80 \pm 8.82$ & & & & \\
\hline \multirow{3}{*}{$\begin{array}{l}\text { CHO } \\
55-60 \%\end{array}$} & 1 & $51.237 \pm 7.27$ & $49.86 \pm 7.01$ & \multirow{3}{*}{$0.003^{* *}$} & \multirow{3}{*}{0.175} & \multirow{3}{*}{$\begin{array}{l}1-3 \\
2-3\end{array}$} & \\
\hline & 2 & $52.97 \pm 7.91$ & $52.27 \pm 7.06$ & & & & \\
\hline & 3 & $45.52 \pm 10.38$ & $50.80 \pm 8.65$ & & & & \\
\hline \multirow{3}{*}{$\begin{array}{l}\text { Energy } \\
\text { expenditure } \\
\text { (cal/d) }\end{array}$} & 1 & $2596.80 \pm 390.57$ & $2507.11 \pm 301.42$ & \multirow{3}{*}{$0.000 * * *$} & & $1-2$ & $1-2$ \\
\hline & 2 & $3308.40 \pm 541.51$ & $2964.05 \pm 409.88$ & & $0.000 * * *$ & $3-1$ & $3-1$ \\
\hline & 3 & $3777.92 \pm 687.16$ & $3647.52 \pm 521.40$ & & & $2-3$ & $2-3$ \\
\hline
\end{tabular}

${ }^{*} \mathrm{p}<0.05, \quad{ }^{* *} \mathrm{p}<0.001,{ }^{* * *} \mathrm{p}<0.001$,

BMI:

1-Defined as BMI Underweight (UW) $\leq 5$ th (Boy $n=30$, Girl $n=44)$,

2- Defined as BMI Normal weight $(\mathrm{NW}) \geq 5$ th $-<85$ th $($ Boy $n=42$,Girl $n=99)$,

3- Defined as BMI Overweight (OW) $\geq 85$ th $-<95$ th (Boy $n=25$, Girl $n=25)$.

\subsection{Energy from fat, according to BMI}

The percentage of total energy from fat was higher than the recommended level for both boys and girls. The rate of energy from fat for boys and girls was higher for UW and OW students than the group with normal BMI. The difference for energy coming from fat for both boys and girls in all BMI groups was significant (boys $\mathrm{p}=0.011$, girls $\mathrm{p}=0.009$ ).

\subsection{Energy from carbohydrates, according to BMI}

The percentage of total daily energy intake from carbohydrates in all groups was lower than the recommended values for Turkey. While the percentage of energy from carbohydrates in NW and UW boys were similar to each other, it was much lower in OW students. While the difference for the energy rate from carbohydrates in girls was not significant, it was significant for boys $(p=0.003)$. For both boys and girls, as the total daily energy spent increased, BMI also increased. The difference for the energy spent between each one of the BMI groups was significant $(p=0.000)$. 
Kucukkomurler S., \& Istik O. (2016). Energy intake, energy dispersion and body mass index interaction in adolescents. Journal of Human Sciences, 13(2), 2793-2803. doi:10.14687/ihs.v13i2.3849

\section{Discussion}

The period of adolescence is the most important in the transition from childhood to adulthood. The nutrition of the young at these ages impacts their later life directly. In a study carried out in Turkey, it was found that the rate of UW and OW varies from 5\% to 30\% (Özdemir, Erçevik and Çalıskan, 2005). In another study conducted with 12-17 year-old adolescents, the rate of being UW was 10-37\% (Bundak, et al, 2006). Aslan et al, (2003) found that 36\% of the girl students were UW and 4\% were obese with respect to BMI-percentile values. In this study, 28\% of adolescents were UW and 19\% were OW; there was no obese group. The rate of obesity is higher in developed countries (Dehghan, Akhtar-Danesh and Merchant, 2005). In a study conducted by the National Center for Health Statistics (NCHS) in the USA with 2-19 year-olds showed that obesity was 16.3\% in the USA and 5\% in Europe (Evans, et al, 2005).

In the investigation into the relation between BMI and adipose tissue, it is recommended that adipose tissue is taken into consideration while using BMI for the purpose of scanning. Low adipose tissue was seen in boys with a high BMI value, as well (Brann, 2008). BFP curves were the same for girls and boys until the age of 9. While BFP was low for boys until the age of 11, it started to increase with the onset of adolescence. It reached $17.0-27.8 \%$ for both girls and boys by the age of 18 on average (Laurson, Eisenmann and Welk, 2011). In this study, BMI means were between 18.19 \pm 2.69 and 20.42 \pm 4.85 .Even though there was no significant difference between boy and girl adolescents, BMI values for girls, except 12 year-olds, were slightly higher at the ages of 13-15. This might be caused by the fact that boys reach adolescence later.

BFP was low in the current study with $38.1 \%$. Adipose tissue rate over $25 \%$ was seen in $35.2 \%$ of the 15 year-olds.BMI and BFP rates were similar to each other.BFP rate was slightly higher in boys compared to girls. Evaluating boys and girls in their own groups, as BMI rates increased, BFP rates also increased; however, it was above normal for OW girls (32.60土5.67).

In a study carried out with healthy girls between the ages of 10-15, energy intake and energy spending were compared. It was found that BMI was 16.8 \pm 1.9 and BFP was $24.0 \pm 4.6$ (Bandini, et al, 2003). In some studies it was found that visceral fat build-up, in particular, increases depending on increasing body fat amounts and could lead to an increase of cardiovascular risk factors (Ebbeling, Pawlak and Ludwig, 2002). It is not clear how the changes in body fat during adolescence occur and what factors are causing it (Dietz, and Gortmaker, 2001). While BFR in the UW were at normal levels, it decreased in those OW.

Total daily energy spending for Turkey was within the recommended range (NGPT, 2004); as BMI values in adolescents decreased, energy intake increased. Energy intake for OW boys was higher than other groups. In the case of increasing and decreasing BMI values, the energy intake coming from protein increased. Zalilah et al, (2006) found that 15\% of energy comes from protein. If this rate increases or decreases, it can cause a disorder in protein metabolism.

The energy percentage from fat was higher than recommended in Turkey for all groups. The energy rate from fat varied between $34-40 \%$. In a similar study carried out in Malaysia, energy from fat was 32-34\% (Zalilah, et al, 2006). In another study, OW children consumed more potato chips and fried potatoes compared to NW children and becoming OW was related to the quality of their diet (Receveur, et al., 2008). In one study, the fat consumption of children ranged between $25 \%$ to $42 \%$. The increase of fat consumption was related to triceps skin folds (Fisher and Birch, 1995). The effect of potential dietary factors on body weight should be carefully reviewed (Ebbeling, Pawlak and Ludwig, 2002). It was noted that changes in OW adolescent habits decrease BMI in the early period when consuming vegetables instead of fruit, snack food with less calories instead of snack food etc. (Hart, et al, 2010). Being OW and obese is related to the intake of high calories and fats. In order to prevent gaining weight, permanent physical environments, balanced diets and physical activity should be pursued (Dehghan, Akhtar-Danesh and Merchant, 2005). 
Kucukkomurler S., \& Istik O. (2016). Energy intake, energy dispersion and body mass index interaction in adolescents. Journal of Human Sciences, 13(2), 2793-2803. doi:10.14687/ihs.v13i2.3849

An important change in adolescent nutrition habits has occurred in the last thirty years. While total energy intake has increased, the energy percentage decreased from $39 \%$ to $32 \%$ and the rate of saturated fat decreased from $15 \%$ to $12 \%$. However, despite this increase in fat rate, there has been an increase in soft drink and non-citrus fruit juice consumption. Whole milk consumption was replaced by low fat milk but total milk consumption has decreased at the rate of $36 \%$. On the other hand, vegetables and fruit consumption are still under the recommended rates (Cavadani, Siega-Riz and Popkin, 2000). While the same menu is offered to children, fat intake from the menu increased by $25-40 \%$. Children prefer fatty food much more compared to other types of food (Fisher and Birch, 1995). It was found in a study that $77 \%$ of adolescents preferred fatty food where $40-50 \%$ of their energy comes from fat (Noi, Schinke and Contento, 2008).

In another study, a parallel relation was found between buying and consuming fried food and BMI (Taveras, et al, 2005). In a study carried out with obese and non-obese children, it was found that the consumption of high calorie foods with low nutrient quality (candy, chips, soda, baked food and ice-cream) was higher in obese children (Bandini, et al, 1999).

In another study carried out investigating the relation between energy-sugar consumption and BMI between 1983-1997, it was found that energy intake increased as an increase in the consumption of sweet foods and soft drinks increased obesity in children. Energy intake was as low as $7 \%$ in 1983 with the real reason being low fat intake. Even so, BMI increased by $0.7-1 \mathrm{~kg} \mathrm{~m}^{2}$ (2-3 $\mathrm{kg}$ ). Average sugar intake increased to $115 \mathrm{~g} / \mathrm{d}$ from $113 \mathrm{~g} / \mathrm{d}$. Energy coming from fat decreased from $35.4 \%$ to $37.8 \%$, while energy rate from sugar increased to $23.6 \%$ from $22.3 \%$. However, besides the foods consumed in this process, the increase in physical activity is as important as energy intake and the BMI relation (Gibson, 2010). In a study carried out with adolescents in the years 1988-1994, it was found that even though total energy intake and the rate of energy from fat decreased, $20-24 \%$ of the energy came from drinks with soft drinks alone accounting for $8 \%$ of energy. The effect of drinks on energy in OW people is higher compared to those who are not OW (Troiano, et al, 2000).

In a study examining diet loss in children between the ages of $1-7,15 \%$ of the total energy in children under 4 came from protein, 36\% from fat, 49\% from carbohydrates and 14\% from sucrose, while the rates for children over 4 were $15 \%, 34 \%, 51 \%$, and $17 \%$, respectively. In this study, the rates of fat and sucrose were very high and carbohydrate rates were very low (Ylönen, et al, 1996). The increase of fat in diets led to an increase in carbohydrates. Consumption of food with high glycaemic index in adolescents stimulates hunger and increases consumption by supporting it hormonally and increases the risk for cardiovascular diseases and Type 2 diabetes. However, there are no long-term clinical studies on this issue (Nicklas, et al, 2001; Ebbeling, Pawlak and Ludwig, 2002).

In order to obtain adequate growth, it is necessary that the energy coming from fat should be $30 \%$ after the age of 2 . Energy coming from fat below 30\% increases the risk for malgrowth due to a lack of vitamin intake. Diets high in fat could lead to an increase in body fat due to a surplus of energy. However, low fat diets in infants and children should be evaluated in terms of maturation, immune defence, and neural development. The role of diet fat in the development of childhood obesity is controversial and not clear. The factors affecting the working fat metabolism of children should be well perceived and be decided over the optimal fat composition (Butte, 2000).

The most effective way to control body weight in adolescents is to not ignore food leading to the feeling of being hungry. Hunger is an important signal. Adolescents should be able to know the value of this signal and choose from food with nutritional value. Even so, it is necessary to take care of the balance of consumed and spent energy (NIH (National Institutes of Health U.S.), 2007). The saturation point of food with higher energy intake is high. However, energy intensity in children's diets is not only directly related to fat but is also related to saturation over time (Ebbeling, 
Kucukkomurler S., \& Istik O. (2016). Energy intake, energy dispersion and body mass index interaction in adolescents. Journal of Human Sciences, 13(2), 2793-2803. doi:10.14687/jhs.v13i2.3849

Pawlak and Ludwig, 2002). It was found in an experimental study that water consumed during a meal led to the feeling of saturation and decreased food intake, therefore it could be used to prevent obesity (Murakami, et al, 2011). In another study, it was pointed out that olive oil rich in mono saturated fat acid could decrease the risk for obesity in children (Haro-Mora, et al, 2011).

For moderately active girls, changes in BMI and the sum of skin fold thickness were midway between those for active and inactive girls. The changes in BMI and fat tissue were clear (Sue, et al, 2005). The most important factor in preventing obesity during adolescence is increasing physical activity. The fact that energy taken in is higher than energy spent could lead to a case where BMI values are high.

In another study it was found that even though OW adolescents chose snack foods less, they preferred fatty, sweet and salty foods much more. The results of the study showed that consuming low energy foods would guarantee body weight (Jodkowska, et al, 2011).

Irazusta et. al. (2007) found that university students consume carbohydrates and foods low in energy and high in fat and protein in their early years of education. It was determined that this kind of nutrition habit could increase the risk of cardiovascular diseases, although diets with low carbohydrates are popular, there is little evidence about the effect of such diets. In a study conducted with OW people with hyperlipidaemia, low fat ketogenic diets and low cholesterol diets were compared with a diet lower in calories. Weight loss was greater in the low fat diet program compared to the one with carbohydrates. However, triglyceride levels in these people decreased while high-density lipoprotein cholesterol levels increased in the low fat diet (Yancy, et al, 2004). The quality of meals could play a significant role in the arrangement of weight from childhood (Huang et al, 2004). In particular, an investigation into the energy distribution as well as the characteristic of diets and total energy could be important in determining the tendency towards obesity. It is necessary to increase physical activities of educators, parents and children with detailed educational campaigns where various institutions take a role and focus on the issue of energy balance through healthy nutrition programs. Making children attain nutrition habits through the period of adolescence is of great importance to maintain a healthy future life.

\section{Conclusion}

The current study found that even though total energy content that adolescent consumed was not high, the energy coming from fat was mostly higher than the rates recommended for Turkey. However, the fact that the amount of energy that was spent is higher circumvents the potential for obesity. A long-term maintenance of this diet could lead to permanent obesity and diseases related to obesity. Adolescents need to know the dietary source of their energy as it is important for healthy eating habits. Professionals working in the field of nutrition should pay attention to the balance of energy sources.

\section{Acknowledgements}

The researchers thank the school administrator and the students for their contribution in carrying out the current study. This study was carried out with the support of Gazi University Scientific Research Projects, no:08/2009-01 (SRP). The authors declare that they have no competing interests. Because this research involves survey procedures, it was exempt from Institutional Review Board approval. 
Kucukkomurler S., \& Istik O. (2016). Energy intake, energy dispersion and body mass index interaction in adolescents. Journal of Human Sciences, 13(2), 2793-2803. doi:10.14687/jhs.v13i2.3849

\section{References}

Aslan D, Gürtan E, Hacim A, et al,(2003). Nutritional Status and Anthropometric Assessment of 10th Grade Girls at a High School in the Catchment Area of Eryaman District, Ankara. Cumburiyet Medical Journal.25:55-62.

Atikessé L, de Grosboi SB, St-Jean M, et al,(2010). Innu Food Consumption Patterns Traditional Food and Body Mass Index. Canadian Journal of Dietetic Pratice and Research.71:41-9.

Bandini LG, Must A, Cyr H, et al,(2003). Longitudinal Changes in the Accuracy of Reported Energy Intake in Girls 10-15 y of Age. American Journal of Clinical Nutrition. 78:480-4.

Bandini LG, Vu D, Must A, et al,(1999). Comparison of High-calorie, Low-nutrient-dense Food Consumption among Obese and Non-obese Adolescents. Obesity Research. 7:438-43.

Bebis (Nutrition information system),(2004). Bebispro for Windows, Stuttgard, Germany: Turkish Version (BeBis 6), (Program uses data from Bundeslebensmittelschlïssel (BLS) 11.3 and USDA 15). Istanbul.

Brann LS,(2008). Classifying Pre-adolescents Boys Based on their Weight Status and Percent Body Fat Produces Different Groups. Journal of the American Dietetic Association. 108:1018-22. doi: 10.1016/j.jada.2008.03.007.

ViewArticle: http://anothersample.net/classifying-preadolescent-boys-based-on-theirweight-status-and-percent-body-fat-produces-different-groups.

Bundak R, Furman A, Gunoz H, et al.,(2006). Body Mass Index References for Turkish Children. Acta Paediatr. 95:194-8.

Butte NF,(2000). Fat Intake of Children in Relation to Energy Requirements. American Journal of Clinical Nutrition. 72:1246-52.

Cavadani C, Siega-Riz AM, Popkin BM,(2000). US Adolescent Food Intake Trends from 19651996. Archives of Disease Childhood. 83:18-24.

Dehghan M, Akhtar-Danesh N, Merchant AT,(2005). Childhood Obesity, Prevalence and Prevention (Review). Nutrition Journal. 2:24.

Dietz WH, Gortmaker SL,(2001). Preventing Obesity in Children and Adolescents. Annual Review of Public Health. 22:337-53.

Ebbeling CB, Pawlak DB, Ludwig DS,(2002). Childhood Obesity: Public-health Crisis, Common Sense Cure. The Lancet. 9331:473-82. doi:10.1016/S0140-6736(02). ViewArticle:https://www.researchgate.net/publication/11148709_Childhood_Obesity_Pu blic-Health_Crisis_Common_Sense_Cure

Evans WD, Finkelstein EA, Kamerow DB, et al,(2005). Public Perceptions of Childhood Obesity. American Journal of Preventive Medicine.28:26-32.

Fisher JO, Birch LL,(1995). Fat Preferences and Fat Consumption of 3-to 5-year-old Children are Related to Parental Adiposity. Journal of the American Dietetic Association. 95:759-64.

Gallagher D, Heymsfield SB, Heo M, et al,(2000). Healthy Percentage Body Fat Ranges: an Approach for Developing Guidelines Based on Body Mass Index. American Journal of Clinical Nutrition. 72:694-701.

Gibson RS,(2005).Principles of Nutritional Assessment, 2nd ed. Oxford, Oxford University Press.

Gibson S,(2010). Trends in Energy and Sugar Intakes and Body Mass Index between 1983 and 1997 among Children in Great Britain. Journal of Human Nutrition and Dietetics. 23:371-81. 24. doi: 10.1111/j.1365-277X.2010.01059.X.

View Article: https://www.google.com.tr/\#q=doi:+10.1111\%2Fj.1365277X.2010.01059.X.

Haro-Mora JI, García-Escobar E, Porras N, et al,(2011). Children Whose Diet Contained Olive Oil had a Lower Likehood of Increasing Their Body Mass Index Z-scor Over 1 Year. Europea journal of Endocrinology.2011;165;435-9. doi:10.1530/EJE-11-0273.

View Article: http://www.eje-online.org/content/165/3/435.abstract 
Kucukkomurler S., \& Istik O. (2016). Energy intake, energy dispersion and body mass index interaction in adolescents. Journal of Human Sciences, 13(2), 2793-2803. doi:10.14687/jhs.v13i2.3849

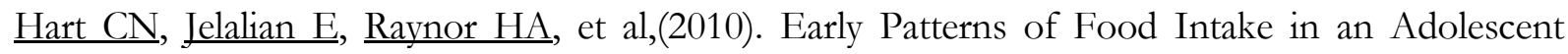
Weight Loss Trial as Predictors of BMI Change. Eating Behaviors.11:217-22. doi: 10.1016/j.eatbeh.2010.05.001.

ViewArticle:

https://www.researchgate.net/publication/46304286 Early patterns of food intake in a n adolescent weight loss trial as predictors of BMI change

Huang TT, Howarth NC, Lin BH, et al,(2004). Energy Intake and Meal Portions: Associations with BMI Percentile in U.S. Children. Obesity Research. 12:1875-85. doi: 10.1038/oby.2004.233.

View Article: http://onlinelibrary.wiley.com/doi/10.1038/oby.2004.233/abstract

Humenikova L, Gates GE,(2007). Dietary Intakes, Physical Activity, and Predictors of Child Obesity among 4-6 $6^{\text {th }}$ Graders in the Czech Republic. Central European Journal of Public Health. 15:23-8. doi: 10.1097/QAD.0b013e32832a128b.

View Article: http://apps.szu.cz/svi/cejph/archiv/2007-1-05.pdf

Institutional Review Board Approval Code of Federal Regulations (45 CFR 46), 46.101: to What Does This Policy Apply (b). Available at: http://www.hhs.gov/ohrp/humansubjects/guidance/45cfr46.html\#46.101 (Accessed June 2013).

Irazusta A, Hoyos I, Irazusta J, et al,(2007). Increased Cardiovascular Risk Associated with Poor Nutritional Habits in First-year University Students. Nutrition Research 27:387-94.

Jodkowska M, Oblacińska A, Tabak I, et al,(2011). Differences in Dietary Patterns between Overweight and Normal-weight Adolescents. Medycyna Wieku Rozwojowego. 15:266-73. doi.org/10.1016/S0140-6736(05)66837-7.

View Article: http://apps.szu.cz/svi/cejph/archiv/2007-1-05.pdf

Kyle UG, Bosaeus I, De Lorenzo AD, et al,(2004). Composition of the ESPEN Working Group. Bioelectrical Impedance Analysis. Part I: Review of Principles and Methods. Clinical Nutrition. 23:1226-43.

Laurson KR, Eisenmann JC, Welk GJ,(2011). Body Fat Percentile Curves for U.S. Children and Adolescents. American Journal of Preventive Medicine. 41:87-92.

Murakami K, Sasaki S, Takahashi Y, et al,(2008). Japan Dietetic Students' Study for Nutrition and Biomarkers Group. Intake of Water from Foods, but Not Water from Beverages, is Related to Lower Body Mass Index and Waist Circumference in Free-living Humans. Nutrition. 24:925-32. doi: 10.1016/j.nut.2008.04.002.

View Article: DOI: http://dx.doi.org/10.1016/i.nut.2008.04.002

NGPT(Nutrition Guide Peculiar to Turkey),(2004). (T.C. Sağllk Bakanllğı Temel Sağllk Hizmetleri Genel Müdürlüğü, Hacettepe Üniversitesi Beslenme ve Diyetetik Bölümü) (Ankara).

Nicklas TA, Baranowski T, Cullen KW, et al,(2001). Eating Patterns, Dietary Quality and Obesity. The Journal of the American of College of Nutrition. 20:599-608.

NIH (National Institutes of Health U.S.),(2007). Biological Sciences Curriculum Study. Bethesda (MD): National Institutes of Health (US).

Noi JD, Schinke SP, Contento IR,(2008). Dietary Fat Intake Among Urban, African American Adolescents. Eating Behavior. 9:251-6. doi http://dx.doi.org/10.1111/j.1468-0297.

View Article: http://www.ncbi.nlm.nih.gov/pubmed/18329605

Özdemir O, Erçevik E, Çalışkan .,(2005). Evaluation of Pupil Growth and Development in Two Primary Schools with Different Socio economic Status. Ankara Üniversitesi T⿰力丶 Fakültesi Dergisi. 58:23-9.

Receveur O, Morou K, Gray-Donald K, et al,(2008). Consumption of Key Food Items is Associated with Excess Weight among Elementary-school-aged Children in a Canadian First Nations Community. Journal of the American Dietetic Association.108:362-6. 

Journal of Human Sciences, 13(2), 2793-2803. doi:10.14687/jhs.v13i2.3849

Sue YS, Kimm MD, Glynn NW, et al,(2005). Relation between the Changes in Physical Activity and Body-mass Index during Adolescence: A Multicentre Longitudinal Study. The Lancet. 9482:301-7.

View Article: doi.org/10.1016/S0140-6736(05)66837-7.

Taveras EM, Berkey CS, Rifaz-Shiman SL, et al,(2005). Association of Consumption of Fried Food away from Home with Body Mass Index and Diet Quality in Older Children and Adolescents. Paediatr. 116:518-24.

Troiano RP, Briefel RR, Carroll MD, et al,(2000). Energy and Fat Intakes of Children and Adolescents in The United States: Data from the National Health and Nutrition Examination Surveys. American Journal of Clinical Nutrition. 72:1343-53.

Wang Y, Wang JQ,(2002). A Comparison of International References for the Assessment of Child and Adolescent Overweight and Obesity in Different Populations. European Journal of Clinical Nutrition. 56:973-82.

Yancy WS, Olsen MK, Guyton JR, et al,(2004). A Low-carbohydrate, Ketogenic Diet Versus a Low-fat Diet to Treat Obesity and Hyperlipidaemia: A Randomized, Controlled. Annals of Internal Medicine. 141:738-9.

Ylönen K, Virtanen SM, Ala-Venna E, et al,(1996). Composition of Diet in Relation to Fat Intake of Children Aged 1-7 years. Journal of Human Nutrition and Dietetics.9:207-18.

Zalilah MS, Khor GL, Mirnalini K, et al,(2006). Dietary Intake, Physical Activity and Energy Expenditure of Malaysian Adolescents. Singapore Medical Journal. 47:491-8. 